\title{
Hydro-meteorologic Assessment of October 2015 Extreme Precipitation Event on Santee Experimental Forest Watersheds, South Carolina
}

\author{
Devendra M. Amatya ${ }^{1}$, Charles A. Harrison ${ }^{2}$, Carl C. Trettin ${ }^{3}$
}

AUTHORS: ${ }^{1}$ Research Hydrologist, ${ }^{2}$ Hydrologic Technician, and ${ }^{3}$ Team Leader, respectively, Center for Forested Wetlands Research, USDA Forest Service, 3734 Highway 402, Cordesville, SC 29434, USA.

\begin{abstract}
The extreme precipitation event on October 3-4, 2015, likely resulting from the convergence of a persistent deep easterly flow, the continuous supply of moisture, the terrain, and the circulation associated with Hurricane Joaquin off the eastern Atlantic Coast (http://cms.met.psu. edu/sref/severe/2015/04Oct2015.pdf) resulted in extreme and prolonged flooding in many parts of South Carolina. We present the precipitation amounts and intensities observed at four gauges on the USDA Forest Service Santee Experimental Forest (SEF) watersheds during this extreme event in conjunction with the antecedent conditions for 5 days prior to the event. All four rain gauges recorded 24-hr maximum rainfall of $340 \mathrm{~mm}$ or more during October 3-4, exceeding the Natural Resource Conservation Service (NRCS) 100-yr 24-hr design rainfall data. The 5-day antecedent measured rainfall prior to October 3 already exceeded $170 \mathrm{~mm}$ in three of the four gauges resulting in weekly (September 28-October 4) totals exceeding $625 \mathrm{~mm}$ in all gauges. Local surface water ponding of as much as $0.46 \mathrm{~m}$ above land surface was observed on one of the groundwater wells at an elevation of $10.395 \mathrm{~m}$. The recorded stage heights at one $1^{\text {st }}$ order (WS 80) and one- $2^{\text {nd }}$ order (WS79) watershed gauging stations over topped the compound weir (WS 80) and weir/culvert (WS 79) outlets, with the highest stages coming near the invert of the bridge above the weir gauges and inundating large riparian areas upstream of them. Preliminary calculations yielded peak flood discharges of at least $17.4 \mathrm{~m}^{3} \mathrm{~s}^{-1}\left(10.9 \mathrm{~m}^{3} \mathrm{~s}^{-1} \mathrm{~km}^{-2}\right.$ or 996 $\left.\mathrm{cfs} / \mathrm{mi}^{2}\right)$ and $33.9 \mathrm{~m}^{3} \mathrm{~s}^{-1}\left(6.8 \mathrm{~m}^{3} \mathrm{~s}^{-1} \mathrm{~km}^{-2}\right.$ or $\left.620 \mathrm{cfs} / \mathrm{mi}^{2}\right)$ for a $1^{\text {st }}$ and $2^{\text {nd }}$ order watersheds, respectively. These values exceeded the previously measured peak discharges within a 25 -year record of $3.8 \mathrm{~m}^{3} \mathrm{~s}^{-1}$ and $11.2 \mathrm{~m}^{3} \mathrm{~s}^{-1}$ for these two watersheds that were recorded on October 24, 2008. When compared with computed design discharges the estimated peak flood discharges on October 4, 2015 exceed the values for a 500-yr return period. These extreme peak flood discharge results may provide insights for a need to revisit existing approaches for hydrologic analyses and design of cross drainage and other water management structures as concerns about extreme storm events resulting from global warming continue.
\end{abstract}

\section{INTRODUCTION}

Increasing surface temperature and evaporation and other extreme weather events, including tropical depressions and hurricanes, collectively contribute to extreme precipitation events in some regions and severe droughts in others. In recent years, conditions are increasingly being linked with global warming and climate change. In the near future, the Southeast is expected to have a more variable climate with temperatures increasing between approximately 2 to $4^{\circ} \mathrm{C}$ and more days exceeding $35^{\circ} \mathrm{C}$ by the end of the century (McNulty et al., 2013). Precipitation forecasts are more variable, and while some models suggest minimal change, this could be an artifact of the regional position between the Southwest, where precipitation is expected to decrease, and the Northeast, where precipitation is expected to increase (Carter et al., 2014). Parts of the country are predicted to experience more total rainfall per year and more frequent extreme rainfall events (Hutton et al., 2015).

Mizzell et al. (2014) examined the local climate variability using data from 66 sites in South Carolina in order to monitor the State's climate signal and better understand the complex controls on the region's climate. Regarding the extreme events, the authors noted that there did not seem to be an increasing trend in tornadoes and hurricanes, nor was there any evidence that these events are becoming less frequent or severe. Dai et al. (2013a) analyzed long-term (1946-2008) climatic data from a weather station at the USDA Forest Service Santee Experimental Forest (SEF) in Cordesville, Coastal South Carolina, and reported an increase in frequency of storms $>50 \mathrm{~mm}$ size during the 1982-2008 period. The largest precipitation event that occurred on the SEF during period of the Dai et al. study was on October 24-25, 2008 with a rainfall total of $157 \mathrm{~mm}$ in 24 hours.

The extreme precipitation event that occurred throughout most of the State of South Carolina (http://cms.met.psu.edu/ sref/severe/2015/04Oct2015.pdf) on October 3-4, 2015 likely resulted from the convergence of a persistent deep easterly flow, and the continuous supply of moisture from the circulation of moisture laden air associated with Hurricane Joaquin off the 
eastern Atlantic Coast. The resulting precipitation resulted in extreme and prolonged flooding in many parts of South Carolina. The most intense rain bands moved over South Carolina after 0600 UTC 4 October, with the single most significant accumulation occurring in the 6-hour period ending 1200 UTC 4 October 2015 (Grumm, 2015). The author reported that the total Stage-IV rainfall amounts exceeded 500 $\mathrm{mm}$ for at least nine sites in the State. The event has been reported to have a return period of as much as 1 in 1000 years (https://www.climate.gov/news-features/event-tracker/ thousand-year-deluge-south-carolina).

Hydrologists are concerned with high-intensity rainfall and peak runoff rates for stormwater infrastructure design, post-event assessments, and mitigation of environmental impacts (Keefer et al., 2015). This is because most regions of the country have stormwater systems and cross-drainage structures designed for specified design return period storms based on tolerable risks for the given system/infrastructure (Obeysekara and Salas, 2016; Hutton et al., 2015; Marion et al., 2013; Feaster et al., 2014). Increases in the return period of large storms, as predicted by many global climate models, may stress existing stormwater infrastructure, depending on the design criteria, (Hutton et al., 2015) and thereby force consideration of replacement with larger size structures to accommodate peak discharges with more frequent return intervals (Marion et al., 2013).

Therefore, reliable estimates of the magnitude and frequency of flood discharges that account for the extreme events are becoming crucial for the design of transportation and water-conveyance structures, flood-plain management and risk analysis. Information on flood frequency and risk assessment is limited for forest land management (Hansen, 1987) and will be critical to future management of forest land and its infrastructure with changing climate conditions. A preliminary flood frequency analysis conducted by Amatya and Radecki-Pawlik (2007) employing Pearson III-type distribution for 100-, 50-, 25, 10- and 5-year return periods using only limited data for forested watersheds of varying scales at the Santee Experimental Forest (SEF) found the results in good agreement with those from the USGSdeveloped formulae for the South Carolina Coastal Plain.

The main objectives of this paper are to a) present the precipitation amounts and intensities observed at four gauges on the USDA Forest Service Santee Experimental Forest (SEF) watersheds during and 5-day prior to this extreme event and b) obtain the preliminary flood discharge estimates for the low-gradient $1^{\text {st }}, 2^{\text {nd }}$, and $3^{\text {rd }}$ order watersheds at Santee Experimental Forest on the South Carolina lower coastal plain.

\section{SITE AND PROJECT DESCRIPTION}

The Santee Experimental Forest was established in 1937 by the U.S. Department of Agriculture Forest Service near Charleston in coastal South Carolina (http://www. srs.fs.usda.gov/charleston/santee/index.html) to support long-term scientific studies of coastal forest ecosystems and their management (Amatya and Trettin, 2007). This study site is located at $33.15^{\circ} \mathrm{N}, 79.8^{\circ} \mathrm{W}$ within the Santee Experimental Forest near the town of Huger (Figure 1).

Two headwater watersheds (WS 77 and WS 80) drain first-order streams to the Fox Gully Creek watershed (WS 79) which in turn drains into Turkey Creek, a tributary of Huger Creek, draining to the East Cooper River, a major tributary of the Cooper River forming the Charleston Harbor System (Figure 1). These low-gradient watersheds, with elevations from 2 to $14 \mathrm{~m}$ above sea level (a.s.l.) and 0 to $3 \%$ slopes, were instrumented in the mid-1960s to study water budget, rainfall-runoff processes, flooding patterns, and effects of rainfall on water table depth and soil moisture (Amatya and Trettin, 2007) in the pine-mixed hardwood coastal forest ecosystems.

The SEF site and the surrounding area experienced the full force of an extreme event (Category IV Hurricane Hugo) on September 21, 1989. Over 80\% of the trees were destroyed, and nine long-term studies were prematurely terminated due to storm damage (Williams et al., 2013; Hook et al., 1991). Much of the area has been naturally regenerated to loblolly and longleaf pine or bottomland hardwoods since Hurricane Hugo (Amatya et al., 2006; 2015). Jayakaran et al. (2014) showed the temporal and spatial change in vegetation dynamics after the hurricane damage to selected stands to be a primary cause of the observed reversal of the runoff-to-rainfall relationship on WS77 and WS80. Furthermore, 63 years (1946-2008) of climatic data from a long-term weather station at the SEF and more than 30 years of streamflow and water chemistry data from the multiple gauged watersheds were analyzed recently by Dai et al. (2013a) to describe the trend, effects of climatic variability and change as well as water and carbon balance of this coastal forest. These results can serve as a basis for assessing impacts of stormwater management, land use and climate change on coastal watersheds linked to tidal freshwater forests in the region characterized by a rapidly growing population and associated residential and commercial development as well as a forest resource base that supports both commercial values in terms of the wood products industry and societal values (e.g., example water supply, cultural history, scenery, and recreational activities) (Amatya et al., 2016).

\section{Data Collection}

\section{METHODS}

\section{$\underline{\text { Rainfall }}$}

Rainfall data was collected using automatic tipping bucket rain gauges verified by manual gauges at four stations (Santee HQ Met at Santee Experimental Forest (SEF) Headquarters, Met5 on WS 77, Met25 on WS 80, and TC Met on WS 78 (Turkey Creek watershed) as shown in Figure 1. Two automatic rain gauges located near the middle, 


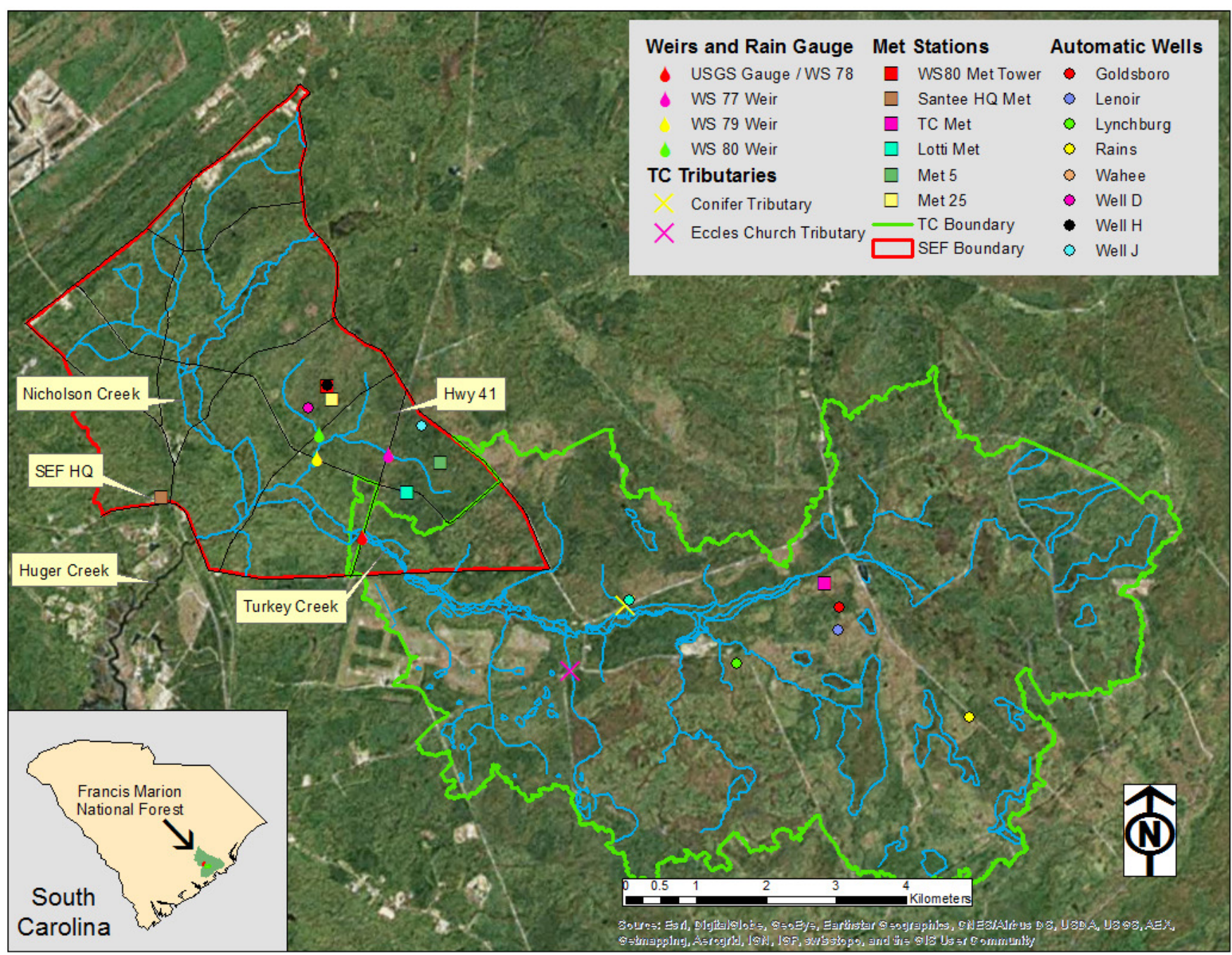

Figure 1. Location map of the rain gauges, flow gauging stations (Weirs), Met stations (either full or partial weather stations), and groundwater wells (Automatic monitoring wells) distributed within the Santee Experimental Forest (SEF) and Turkey Creek watershed on the Francis Marion National Forest, Coastal South Carolina.

large open area of the Turkey Creek (TC) watershed (WS78) included a Texas Electronics, Inc. Model TR-525USW attached to a Campbell Scientific CR10X datalogger and a Sierra-Misco Environmental Ltd. Model 2501 gauge. Onset Model RG2M tipping bucket gauges hooked to Onset HOBO Pendant event dataloggers were located at the Met5 and Met25 stations in wide open areas of the watersheds WS 77 and WS 80, respectively. Finally a Texas Electronics, Inc. Model TE-525MM rain gauge linked to a Campbell Scientific CR10X datalogger was located at the SEF (Santee Headquarter Met) (Figure 1). Data from each of the automatic rain gauges were verified and calibrated using an adjacent manual rain gauge (Dai et al., 2013a; Amatya et. al., 2009). Rainfall data from both the tipping buckets and manual gauges are collected on a weekly to biweekly basis.
Adjustment of rainfall data for the extreme event on October 3-5, 2015

Because all of the existing standard $200 \mathrm{~mm}$ (8") diameter US Weather Bureau rain gauges were filled beyond capacity during this extreme rain event, estimate of the total rainfall at a particular gauge site for the event was obtained by multiplying the ratio of manually-measured rainfall to tipping bucket total rainfall for the preceding "good" interval before October 3 by the tipping bucket total during the overfilling period.

\section{Water Table}

Water table elevations were recorded on an hourly basis in 2.5 to $3.0 \mathrm{~m}$ deep $40 \mathrm{~mm}$ diameter PVC recording wells (Well H and Well D on WS 80, Well J on WS 77, and five wells on Goldsboro, Lenoir, Lynchburg, Rains, and Wahee soils on WS 78) equipped with WL16 dataloggers (Figure 1). While elevations for the wells D, H, and J were obtained by topographical survey in 2003, $1.5 \mathrm{~m} \mathrm{x} 1.5 \mathrm{~m}$ high resolution ( $0.15 \mathrm{~m}$ average vertical accuracy) LiDAR- 
based digital elevation model (DEM) was used to estimate the approximate elevations for all the wells on WS 78 watershed. Water table data are generally downloaded on a biweekly basis and appropriate quality control of the data is conducted by comparing with manual measurements as well as with corresponding rainfall events for potential discrepancies.

\section{$\underline{\text { Streamflow }}$}

Continuous stage heights were monitored at 10-minute intervals at stream gauging stations of watersheds WS 77, WS 80, and WS 79 to obtain their flow records. Streamflow rates on both watersheds (WS 77 and WS 80) with a compound $\mathrm{V}$-notch and a flat weir were estimated using a rating curve developed for such weirs and measured stage heights at the gauging stations. Streamflow rates for watershed WS 79 with a compound V-notch weir at the center with a $3.33 \mathrm{~m}$ wide and $1.2 \mathrm{~m}$ high box culvert on either side were estimated using the standard weir and box culvert equations. Stream gauging data and flow estimates for these watersheds have been available since 1964 with intermittent data gaps, with the largest gap between 1981 and 1989 (Amatya and Trettin, 2007). Data collected since 2003 have been almost continuously available.

\section{Adjustment of stream gauge height for the extreme event}

Stage at the WS 80 gauging station is normally measured in 10-minute intervals by a Teledyne-ISCO 4210 flow meter with ultrasonic Doppler sensor. However, during an approximately 28-hour period from 10/3/15 21:10 to 10/5/15 $0: 50$, this sensor was submerged by the exceptionally large flows resulting from the extreme rain event. However, a Global Water GL500 data logger with pressure transducer serving as a backup continued to collect during this submergence period. A regression equation (Stage_4210 $=1.003 *$ Stage_GL500 $-1.288 ; \mathrm{R}^{2}=0.99$ ) obtained by using 10 -minute stage data collected by both instruments during the 10/1/15 0:00 to 10/3/15 21:00 and 10/5/15 1:00 to 10/9/15 21:00 periods was applied to estimate the missing data. A similar method was used to estimate missing stage data at the WS 77 and WS 79 ( $2^{\text {nd }}$ order watershed) gauging stations.

A real-time USGS stream gauging station (http:// waterdata.usgs.gov/sc/nwis/uv?site_no $=02172035$ ) at the main outlet of the watershed WS78 collected stage heights at a 15-minute interval using a Sutron data-logger interfaced with a bubbler-type sensor mounted to the streambed. Flow rates were calculated using a stage-discharge relationship developed by the USGS using frequent in-situ manual velocity measurements with a Marsh-McBirney flow meter at the stream cross section where the station is located (Amatya and Jha, 2011). However, the flow conditions at this gauge were not evaluated in this study.

Details of other hydrologic monitoring stations and data processing procedures for these watersheds have been reported elsewhere (Amatya and Trettin, 2007; 2009; Dai et al., 2013a; Harder et al., 2007). Data from all these monitoring stations can be accessed at http://www.srs. fs.usda.gov/charleston/santee/data.html.

\section{Data Analysis}

Instantaneous rainfall data from all automatic gauges were processed to obtain 1-hr, 3-hr, 6-hr, 12-hr, and 24-hr (daily) moving maximum totals for the month of September-October 2015 and daily rainfall was further integrated to obtain the 5-day (September 28-October 02) total prior to the event as antecedent conditions. Monthly rainfall obtained from daily values in 2015 was compared with the monthly mean rainfall observed in the last 12 years (2003 to 2014) as well as for the historic period. A daily rainfall frequency-duration curve was constructed using data from 2003 to 2015 only as an example for this paper for the rain gauge at Met5 on watershed WS 77.

Hourly maximum water table depths measured on all the groundwater wells for the extreme event of October 3-4, 2015 were identified to analyze the spatial extent of saturation and flooding on all the watersheds. The data were also put in the context of the previous extreme event of October 24, 2008 and the long-term (2006-2015) measurement period.

Maximum gauge stage heights measured during the extreme event of October 3-4, 2015 were documented and compared to the previous extreme event of October 24, 2008 measurement period. The October 3-4, 2015 extreme storm event has been reported to have produced flood discharges of return periods of 500 -yr or less in the South Carolina lower coastal plain (Grumm, 2015). Accordingly, we made preliminary assessments of the peak discharge estimates for the 100-, 200-, and 500-yr return periods using various methods applicable to the low-gradient South Carolina coastal plain as outlined below:

1) One parameter (drainage area) design discharge formula (Feaster et al., 2009) for 100-yr and 500-yr return periods

2) Three parameters (drainage area, impervious area, and 50-yr 24-hr maximum rainfall) formula (Feaster et al., 2014) also for 100-yr and 500-yr return periods

3) Flood frequency formulas for 100- and 200-yr return periods developed with the limited historic data for the study watersheds (Amatya and Radecki-Pawlik, 2007)

4) Two parameter (drainage area and total runoff) peak discharge formula (Sheridan, 2002)

5) Maximum discharge capacity of gauging station outlets using measured stages

Total runoff parameter used in Sheridan (2002) formula to estimate peak discharge was assumed as the excess rainfall which was defined as the rainfall that occurred after the watersheds were completely saturated and inundated with negligible storage based on the measured ponding in all groundwater wells in the watersheds. Water table data from wells across the watersheds were used to assess the saturation and ponding during the event.

Maximum discharge capacities of gauging station outlets were computed using the observed maximum gauge stages with appropriate hydraulic equations for standard V-notch and flatcrested weirs as well as for culverts (Brater et al., 1996) for stage outlets of WS 77, WS79, and WS 80. Since the observed gauge stage heights at the weir/culvert outlets under bridges both on 
the WS 79 and WS 80 sites exceeded the available openings on October 4, the peak of the extreme event of October 3-4, 2015, equations for submerged inlet conditions were used. A submerged box culvert type flow with a reduced discharge coefficient was assumed to occur also in the bridge opening above the WS 80 weir as described below. The peak flood discharge estimates for the largest $3^{\text {rd }}$ order watershed (WS 78) were analyzed by the USGS, however, and are not reported herein.

A preliminary water balance calculation for the year 2015 was conducted using the measured rainfall, stream flow, and water table depths for the $1^{\text {st }}$ order control watershed (WS 80) and discussed with respect to its long-term data.

\section{RESULTS}

\section{Rainfall}

The 12-year monthly mean rainfall (with standard deviations as vertical bars) obtained using daily rainfall from 2003 to 2014 for the Met5 gauge (as an example) is compared with the measured monthly rainfall in 2015 in Figure 2. The seasonal monthly distribution in 2015 with the October extreme event had higher rainfall in eight out of the 12 months, with significantly higher rainfall $(686 \mathrm{~mm})$ in October that was more than 7.5 times the 12-year October mean of only $89 \mathrm{~mm}$. Similarly, August also had much higher rainfall of $258 \mathrm{~mm}$ compared to its 12-year mean $(153 \mathrm{~mm})$. The monthly totals for September in 2015 varied from $128 \mathrm{~mm}$ at Santee HQ Met gauge to $144 \mathrm{~mm}$ at TC Met gauge and for October varied from $663 \mathrm{~mm}$ at Santee HQ Met gauge to $686 \mathrm{~mm}$ at Met5 gauge, with no significant differences between the gauges for both the months. As a result, the annual total rainfall for 2015 was $2146 \mathrm{~mm}$ and $2095 \mathrm{~mm}$ at the Met 5 and Santee HQ gauges, respectively.

Daily rainfall frequency-duration curves using 13 years of daily rainfall measured on one of the gauges (Met5) on the watershed WS 77 is presented in Figure 3. Clearly, until the

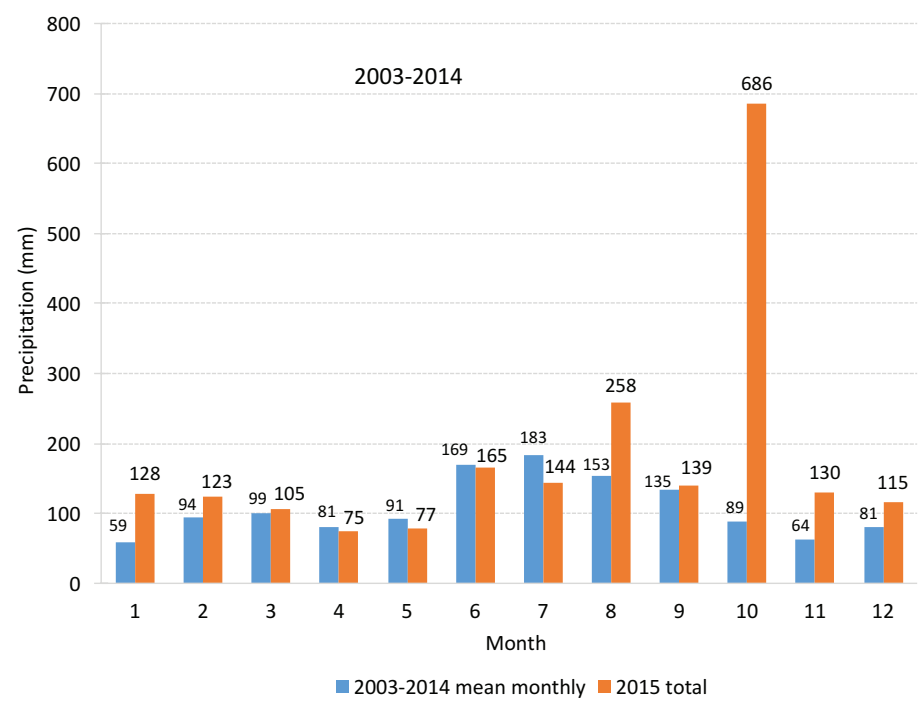

Figure 2. 12-year (2003-2014) measured mean monthly rainfall compared to 2015 monthly rainfall at Met5 rain gauge.
October 3, 2015 extreme event, the largest other daily storm event that occurred during the period of study at the site was on October 24, 2008 with a rainfall amount of $157 \mathrm{~mm}$, followed by an event on September 22, 2014 with $137 \mathrm{~mm}$. Daily rainfall values of $75 \mathrm{~mm}$ or more occurred 12 out of 19 times (in all 13 years) during the last 8 years alone since 2008. Furthermore, 24-hr rainfall amounts of about $100 \mathrm{~mm}$ (4 in) occurred in 7 out of 8 years from 2008 until 2015.

The maximum rainfall amounts measured for various durations over the October 3-5, 2015 extreme event at four rain gauges at SEF are given in Table 1 There were some variabilities in rainfall amounts among the four gauges, as expected, although they were not very large, except for the 3-hr duration between TC and SHQ gauges. The amounts were highest at Met5 for 6-hr or more duration, with amounts at TC the highest for the 1- and 3-hr durations. The 5-day (September 28 - October 2) antecedent rainfall prior to the event itself exceeded $170 \mathrm{~mm}$ in three of the four gauges, with the last two-day (October 3-4) total rainfall of $470 \mathrm{~mm}$ (Table 1).

Daily Rainfall Frequency Duration Curve (2003-2015)

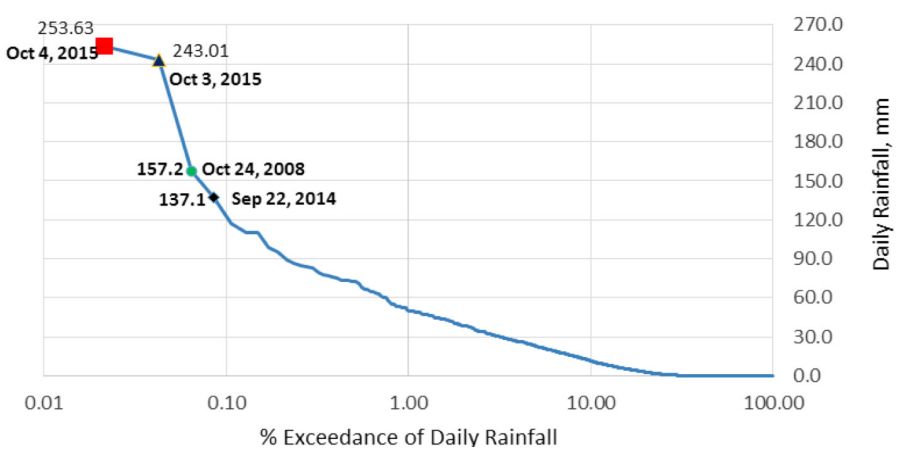

Figure 3. Daily rainfall frequency duration curve using data from January 2003 to October 2015 at Met5 rain gauge.

Table 1. Maximum rainfall amounts for various durations and 5-day antecedent moisture condition (AMC) as sum of five previous days (September 28-October 2) of rainfall prior to October 3, 2015 for four gauges (Met 5, Met 25, Santee HQ, and TC Met). Listed are also the predicted 50- and 100yr rainfall amounts for 1-, 6-, 12-, and 24-hr durations for Charleston County, SC (Purvis et al., 1988).

\begin{tabular}{|c|c|c|c|c|c|c|}
\hline Rainfall & Met 5 & $\begin{array}{c}\text { Met } \\
\mathbf{2 5}\end{array}$ & $\begin{array}{c}\text { Santee } \\
\text { HQ }\end{array}$ & $\begin{array}{c}\text { TC } \\
\text { Met }\end{array}$ & 50-yr & 100-yr \\
\hline Duration & $\mathrm{mm}$ & $\mathrm{mm}$ & $\mathrm{mm}$ & $\mathrm{mm}$ & $\mathrm{mm}$ & $\mathrm{mm}$ \\
\hline AMC & 179.9 & 176.3 & 172.0 & 145.0 & N/A & N/A \\
\hline 1-hr & 65.5 & 62.9 & 57.7 & 75.3 & $\mathbf{9 4 . 7}$ & $\mathbf{1 1 0 . 0}$ \\
\hline 3-hr & 180.4 & 176.5 & 148.2 & 187.4 & N/A & N/A \\
\hline 6-hr & 273.8 & 266.1 & 250.0 & 266.4 & $\mathbf{1 6 2 . 6}$ & $\mathbf{1 7 7 . 8}$ \\
\hline 12-hr & 312.7 & 305.1 & 293.5 & 306.7 & $\mathbf{1 8 9 . 2}$ & $\mathbf{2 1 5 . 9}$ \\
\hline 24-hr & 362.3 & 354.6 & 358.1 & 340.3 & $\mathbf{2 2 6 . 1}$ & $\mathbf{2 5 4 . 0}$ \\
\hline 48-hr & 496.7 & 484.0 & 488.4 & 471.0 & N/A & N/A \\
\hline
\end{tabular}




\section{Analysis of Water Table}

Hourly water table data recorded at seven recording wells on various soil types during the month of October 2015 are presented in Figure 4 along with the hourly rainfall recorded at SHQ gauge. Water table on soils were either ponded (Rains soil) or near surface saturation for all wells, except for the well in Wahee soil at the beginning of September 3, with continuous drawdown thereafter. The water table depth dropped to as much as $150 \mathrm{~cm}$ for the well in Wahee soil due to a 6 day (September 18-23) dry period with only $17 \mathrm{~mm}$ of rainfall from September 3-17, until September 24, which had $30 \mathrm{~mm}$ of rainfall raising the water table to $18.1 \mathrm{~cm}$ from the surface on September 25 in the Rains soil (Figure 4). With accumulated rainfall of 170 $\mathrm{mm}$ or more as antecedent wet conditions existed 5 days prior to October 2 (Table 1), water ponding continued at the wells in the Rains and Lenoir soils and developed at all wells resulting in surface ponding of as much as $46.3 \mathrm{~cm}$ for the Lenoir well followed by $40.7 \mathrm{~cm}$ for the Rains well by late night of October 3 with 24-hr rainfall amounts at the maximum in all four gauges (Table 2). Only the well D on WS80 had water table depth at 9 $\mathrm{cm}$ below the surface (Table 2).

\section{Peak Flood Discharge Estimates}

\section{WS 80 Gauging Station}

Figure 5A shows the WS 80 stream gauging station with a compound V-notch weir in the center below the bridge and Figure 5B shows the measured stage from the V-notch bottom for the storm event of October 3-4, 2015. The current full opening of $1.2 \mathrm{~m}$ height from bottom of the V-notch weir to the invert of the bridge beam across the $8.53 \mathrm{~m}$ wide compound weir allows a maximum discharge of $12.7 \mathrm{~m}^{3 /} \mathrm{s}$. However, the peak stage of $1.448 \mathrm{~m}$ measured at the gauging station shown by the red line in Figure 5A in the early morning of October 4, 2015 exceeded the full stage by 0.343 $\mathrm{m}$, reaching the concrete beam under the bridge and yielding an estimated preliminary peak discharge of $17.3 \mathrm{~m}^{3 /} \mathrm{s}$ (Table 3). The event also yielded multiple small peak stages due to intermittent smaller rainfall prior to and after the $48-\mathrm{hr}$ extreme amount exceeding $480 \mathrm{~mm}$ at Met 25 gauge on the WS 80 watershed (Table 1; Figure 4). The flow hydrograph corresponding to the measured stage is not shown here.

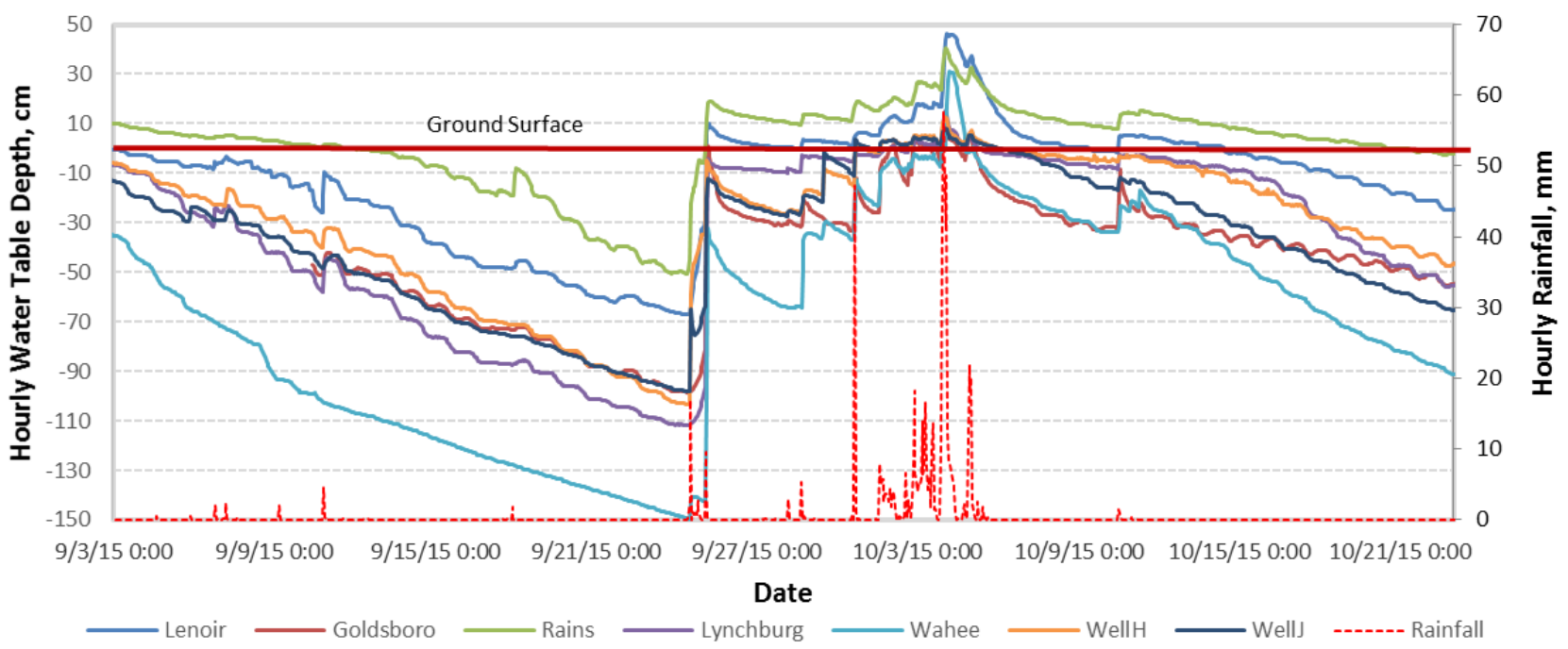

Figure 4. Measured hourly rainfall at Santee Headquarters (SHQ) gauge and hourly water table depths recorded across seven groundwater wells in October 2015 with an extreme event.

Table 2. Maximum hourly water table depths measured on two extreme events at various groundwater wells across the Santee Experimental Forest and Turkey Creek watershed compared with October average and standard deviation in parentheses for 2006-15 period.

\begin{tabular}{|l|c|c|c|c|}
\hline Groundwater Wells & $\begin{array}{c}\text { Ground surface } \\
\text { elevation at the } \\
\text { well, } \mathbf{~ m}\end{array}$ & $\begin{array}{c}\text { Water table } \\
\text { depth } \mathbf{( c m )} \text { on } \\
\mathbf{2 4 - O c t - 0 8}\end{array}$ & $\begin{array}{c}\text { Water table } \\
\text { depth }(\mathbf{c m}) \text { on } \\
\mathbf{4 - O c t - 1 5}\end{array}$ & $\begin{array}{c}\mathbf{2 0 0 6 - 2 0 1 5} \text { October } \\
\text { Average water table } \\
\text { depth }(\mathbf{c m})\end{array}$ \\
\hline H-WS80 & 9.086 & $\mathbf{8}$ & 12.5 & $-144.6( \pm 111.6)$ \\
\hline D-WS80 & 7.508 & $\mathbf{- 2 5}$ & $\mathbf{- 9 . 0}$ & $-190.7( \pm 70.7)$ \\
\hline J-WS77 & 9.675 & $\mathbf{2 . 9}$ & $\mathbf{8 . 1}$ & $-78.9( \pm 47.6)$ \\
\hline Goldsboro-WS78 & 10.297 & $\mathbf{- 6 . 1}$ & $\mathbf{7 . 4}$ & $-139.1( \pm 80.5)$ \\
\hline Lenoir-WS78 & 10.395 & $\mathbf{6}$ & $\mathbf{4 6 . 3}$ & $-54.9( \pm 42.3)$ \\
\hline Lynchburg-WS78 & 9.645 & $\mathbf{- 0 . 5}$ & $\mathbf{1 5 . 1}$ & $-94.2( \pm 64.7)$ \\
\hline Rains-WS78 & 10.952 & $\mathbf{1 7 . 3}$ & $\mathbf{4 0 . 7}$ & $-57.0( \pm 53.1)$ \\
\hline Wahee-WS78 & 8.122 & $\mathbf{N} / \mathbf{A}$ & $\mathbf{3 0 . 9}$ & $-142.4( \pm 70.5)$ \\
\hline
\end{tabular}



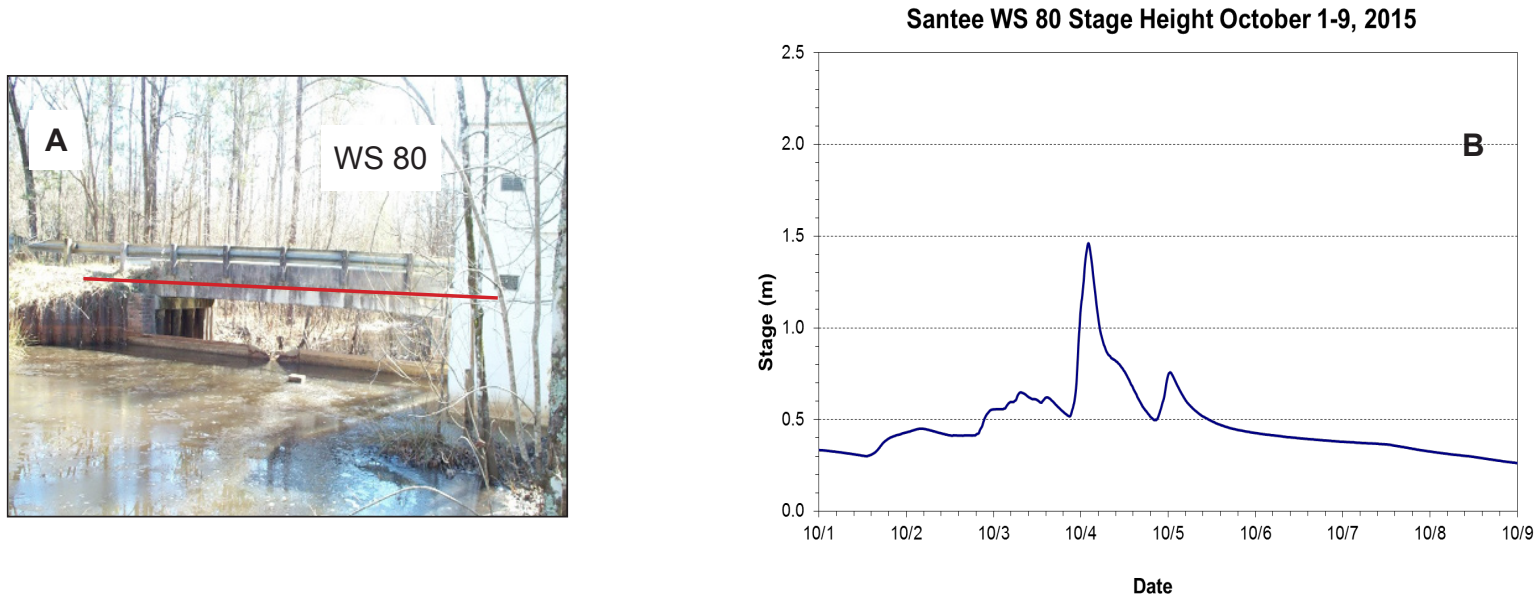

Figure 5. (A) Streamflow gauging station outlet at WS 80 showing the approximate maximum high flood level (HFL, red line on photograph) and (B) the stage hydrograph for the October 3-4, 2015 extreme storm event at WS 80.
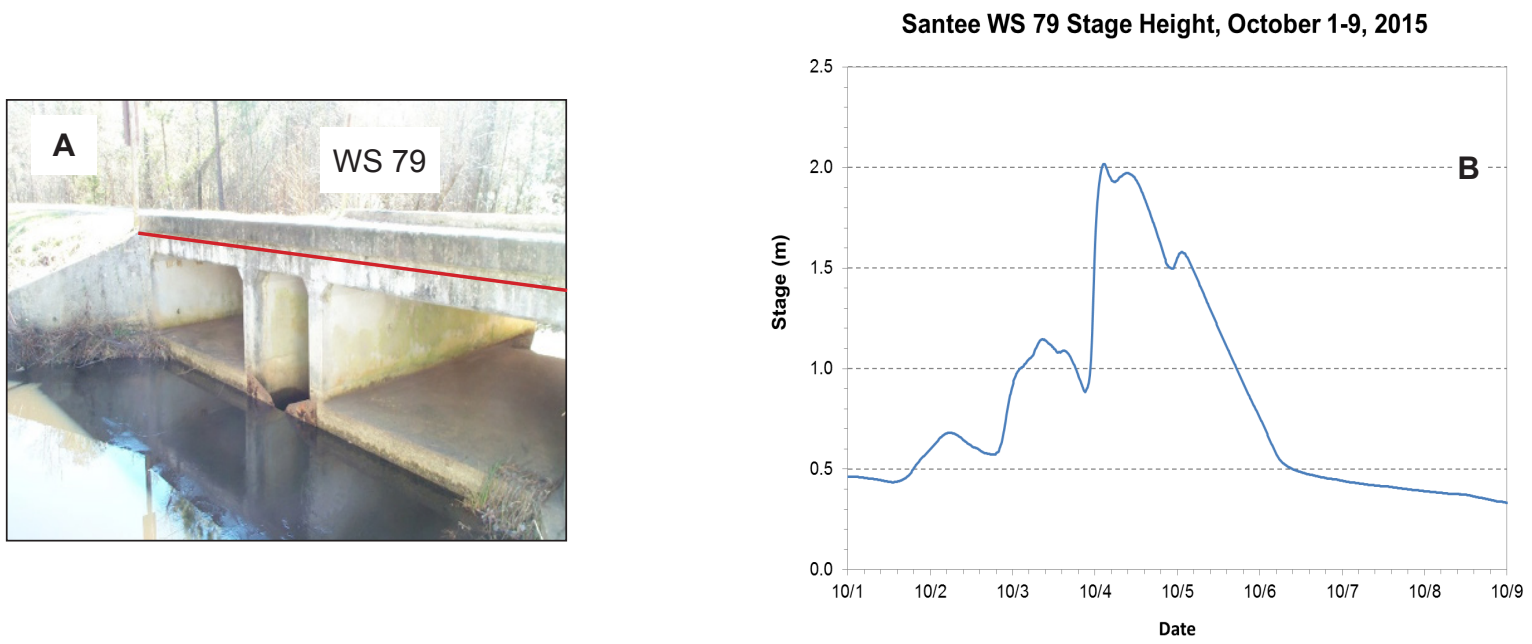

Figure 6. (A) Streamflow gauging station outlet at WS 79 showing the approximate maximum high flood level (HFL, red line on photograph) and (B) stage hydrograph for the October 3-4, 2015 extreme storm event.

\section{WS 79 Stream Gauging Station}

Similarly, Figure 6A shows the WS 79 stream gauging station with a compound V-notch weir below the center box culvert with two other rectangular culverts on its either side below the bridge and Figure $6 \mathrm{~B}$ shows the measured stage above the V-notch bottom for the storm event of October 3-4, 2015. A gauge stage height (head) of $1.569 \mathrm{~m}$ from the bottom of the compound V-notch weir in the center between the two box culverts completely fills the rectangular opening above the weir as well as the side culvert openings with a height of the $1.2 \mathrm{~m}$ from its bottom to the ceiling at the WS 79 outlet yielding an estimated maximum discharge of $26.0 \mathrm{~m}^{3 / \mathrm{s}}$ (Figure 6) just before the submergence of culverts. However, the maximum gauge stage height of $2.009 \mathrm{~m}$, exceeding the full opening by $0.44 \mathrm{~m}$ resulting in submergence observed in the early morning of October 4, 2015 (shown by the red line in left picture of Figure 6). yielded a preliminary peak discharge estimate of $33.9 \mathrm{~m}^{3 / \mathrm{s}}$ (Table 3). As on the WS 80 gauge, the smaller rainfall amounts prior to the extreme event of October 3-4 produced multiple smaller stage peaks. A picture of inundated WS 79 gauge house is presented in Figure 7.
Thus these maximum gauge stage heights clearly indicate that the peak flood discharges during this event substantially exceeded the allowable capacities at both of these gauging station outlets (WS 79 and WS80). The calculated daily flows including these two days during the extreme event in 2015 yielded annual depth-based streamflow of $969.5 \mathrm{~mm}$, with $600.5 \mathrm{~mm}$ of streamflow for the month of October alone for WS 80 watershed.

Interestingly, the measured gauge stage height above the compound V-notch weir during the extreme event at the other $1^{\text {st }}$ order WS 77 watershed gauging station (Figure 1) even went around the vertical brick walls on the sides of the top of the weir without a constricted bridge section (not shown) as in the case of WS 79 and WS 80 outlets complicating its discharge estimate. Therefore, the peak discharge and hydrograph estimates for this watershed will be presented later. Similarly, the peak discharge estimates for the largest $3^{\text {rd }}$ order watershed (WS 78) being conducted by the USGS have not been presented herein and will be presented in a subsequent document. The discharge estimates are available, however, at the USGS web site for the WS 78 watershed at http://waterdata.usgs.gov/sc/nwis/uv?site_no $=02172035$. 
Table 3. Peak flood discharges for 100-yr, 200-yr, and 500-yr return periods estimated using various empirical methods compared to the values obtained using the measured stage heights at the weir/culvert outlets of four watersheds for October 04, 2015 extreme event at Santee Experimental Forest.

\begin{tabular}{|c|c|c|c|c|c|c|c|c|c|c|}
\hline \multirow[t]{2}{*}{$\begin{array}{c}\text { Watershed } \\
\text { Name/\# }\end{array}$} & \multirow[t]{2}{*}{$\begin{array}{c}\text { Drainage } \\
\text { Area }\end{array}$} & \multirow[t]{2}{*}{$\begin{array}{l}\text { Measured } \\
\text { Stage }\end{array}$} & \multicolumn{2}{|c|}{$\begin{array}{l}\text { Amatya \& Radecki- } \\
\text { Pawlik (2007) }\end{array}$} & \multicolumn{2}{|c|}{$\begin{array}{l}\text { Feaster et al. (2009) } \\
\text { Pearson Type-III } \\
\text { equation }\end{array}$} & \multicolumn{2}{|c|}{$\begin{array}{l}\text { Feaster et al. (2014) } \\
\text { 3-parameter } \\
\text { equation }\end{array}$} & \multirow[t]{2}{*}{$\begin{array}{l}\text { Sheridan } \\
\text { (2002) } \\
\text { 2-parameter } \\
\text { equation }\end{array}$} & \multirow[t]{2}{*}{$\begin{array}{l}\text { Using stage } \\
\text { and weirl } \\
\text { culvert eq } \\
10-4-2015\end{array}$} \\
\hline & & & $100-y r$ & $200-y r$ & $100-y r$ & 500-yr & $100-y r$ & $500-y r$ & & \\
\hline & $\mathrm{km}^{2}$ & $\mathrm{~m}$ & $\mathrm{~m}^{3} / \mathrm{s}$ & $\mathrm{m}^{3} / \mathrm{s}$ & $\mathrm{m}^{3} / \mathrm{s}$ & $\mathrm{m}^{3} / \mathrm{s}$ & $\mathrm{m}^{3} / \mathrm{s}$ & $\mathrm{m}^{3} / \mathrm{s}$ & $\mathrm{m}^{3} / \mathrm{s}$ & $\mathrm{m}^{3} / \mathrm{s}$ \\
\hline WS 77 & 1.60 & $\mathrm{~N} / \mathrm{A}$ & $\mathrm{N} / \mathrm{A}$ & $\mathrm{N} / \mathrm{A}$ & 8.1 & 11.8 & 7.8 & 11.0 & 13.8 & N/A \\
\hline WS 80 & 1.55 & 1.45 & 2.1 & 2.3 & 7.9 & 11.5 & 7.6 & 10.8 & 13.2 & 17.3 \\
\hline WS 79 & 4.75 & 2.01 & 12.5 & 15.3 & 15.4 & 22.2 & 15.5 & 21.7 & 28.5 & 33.9 \\
\hline WS 78 & 52.4 & $N / A$ & 45.7 & 49.7 & 64.2 & 89.9 & 67.8 & 98.2 & 96.6 & N/A \\
\hline
\end{tabular}

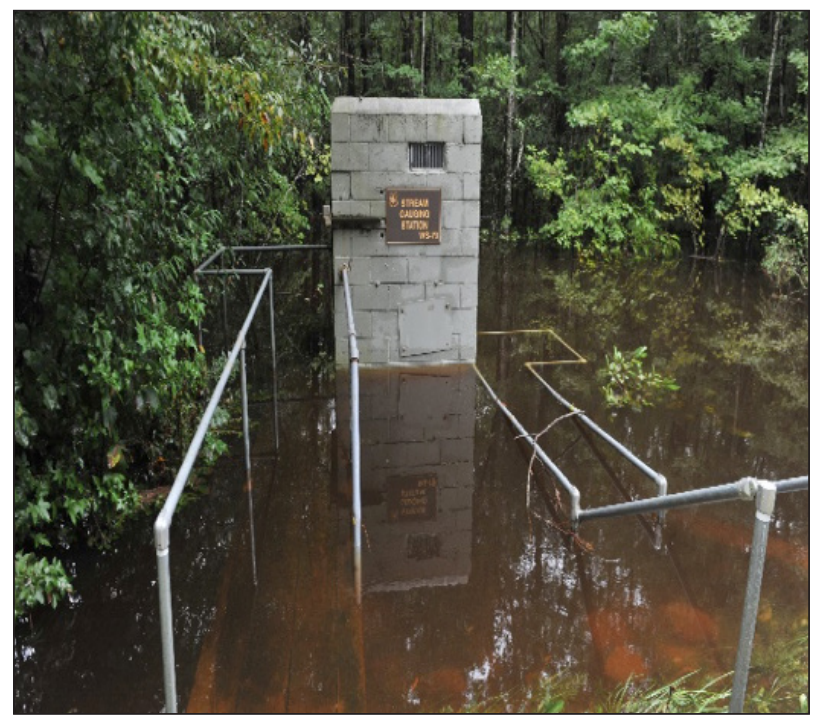

Figure 7. Flooded gauging station at the outlet of $2^{\text {nd }}$ order watershed WS 79 soon after the peak flood on October 4 at Santee Experimental Forest (Courtesy: Ricky Wrenn).

\section{Water Balance}

The annual water balance on the control watershed (WS 80) in 2015 was estimated as $\mathrm{R}=\mathrm{O}-\mathrm{ET} \pm \Delta \mathrm{S}$, where $\mathrm{R}$ $=$ total rainfall $(2171.4 \mathrm{~mm}), \mathrm{O}=$ depth-based streamflow (969.5 $\mathrm{mm}), \mathrm{ET}=$ evapotranspiration, and $\Delta \mathrm{S}=$ change in soil moisture storage, assuming negligible deep seepage. $\Delta \mathrm{S}$ was estimated as a change in watershed storage from January 01 (initial) to December 31 (final), 2015 using the hourly measured water table depth on Well H on WS 80 . Since the measured initial and final water table depths were near surface at only $8.9 \mathrm{~cm}$ and $0.6 \mathrm{~cm}$, respectively, at this upland well, the soils were assumed to be fully saturated and change in storage was approximated negligible. Thus the water balance leaves $1201.9 \mathrm{~mm}$, which is approximated as ET. The annual runoff coefficient, streamflow as a fraction of rainfall, was 0.45 much larger than the 29-year average of 0.22 but about the same as the maximum reported by Dai et al. (2013) and Harder et al. (2007).

\section{DISCUSSION}

The extreme event of October 3-4, 2015 with nearly $500 \mathrm{~mm}$ rainfall (Table 1) in 48 hours resulted in the highest recorded October rainfall of $686 \mathrm{~mm}$ during the last 66 years at the site. As a result, the annual 2015 rainfall of $2146 \mathrm{~mm}$ (at Met5) was the highest recorded annual rainfall during the 66 years record period, but only $99 \mathrm{~mm}$ more than in 1994 with $2047 \mathrm{~mm}$ followed by $2026 \mathrm{~mm}$ in 1999 (Dai et al., 2013a).

The maximum rainfall intensities for 1-hr duration measured were similar to that observed on August 7, 1966 $(69.6 \mathrm{~mm})$ at the study site. The 24-hr maximum rainfall values of at least $340 \mathrm{~mm}$ measured at two gauges (Met 5 and TC) exceeded the 24-hr rainfall of 100 -yr return period value of $241.3 \mathrm{~mm}$ published by NRCS (1986) for this site in the South Carolina coastal region (Table 1), as well as the rainfall amount of about $250 \mathrm{~mm}$ or less observed during previous extreme event of Hurricane Hugo on September 22, 1989. Two other gauges measured slightly lower than the NRCS extreme value. The 48-hr rainfall recording of nearly $500 \mathrm{~mm}$ is similar to record high measurements of at least $500 \mathrm{~mm}$ at nine sites in South Carolina reported by Grumm (2015).

The daily rainfall frequency duration curve using 20032015 data for Met 5 (Figure 3) shows a steep slope at the high intensity rainfall levels. Our observations of increasing high intensity storms over the $2008-2015$ period at the study site are consistent with Dai et al. (2013a), who found that storm sizes of $50 \mathrm{~mm}$ or more have been increasing more frequently than the smaller size events since 1982 based on the analysis of 1946-2008 data. Furthermore, the 24-hr rainfall of about $100 \mathrm{~mm}$ that is estimated to occur once in two years on average (2-yr 24-hr return period) for this coastal region (NRCS, 1986) has occurred, in fact, in 7 out of 8 years from 2008 until 2015. This October 2015 extreme rainfall event, potentially caused by the indirect effects of Hurricane Joaquin, resulted mostly in flooding, in contrast to the severe destruction of forest vegetation driven by Hugo's hurricane force wind speeds exceeding $210 \mathrm{~km} \mathrm{hr}^{-1}$ (130 mph) (Hook et al., 1991). Vose et al. (2016) noted that these types of 
extreme precipitation events are not the only sources of future uncertainty and variation, but other compounded disturbances are also expected to accelerate in the future.

Soils within these forested wetlands often have poorly drained clayey subsurface layers restricting internal drainage, potentially resulting in a high water table. The small topographic gradients of these sites combined with their high water tables cause runoff due to saturation excess mechanism (Sivapalan et al., 1987). On the other hand water table is also influenced by rainfall and evapotranspiration (Harder et al., 2007).

The extreme event caused the water table to rise near the soil surface or caused ponding in or around almost all groundwater wells by early October 4 by inundating large areas around the wells. Water tables on these poorly drained soils potentially respond rapidly to the rainfall amount due to their drainable porosities (Williams, 1978), as was shown by Harder et al. (2007) and Callahan et al. (2012) for the Wahee and Lenoir soils on these watersheds. By October 10, the water table receded below land surface at all the wells, except for the Rains site. This type of response of water table was consistent with an earlier study by Amatya et al. (2009) for a sustained event in September 2006. However, the ponding or water table elevations for all wells was much higher than the response observed in the previous extreme event on October 24, 2008 with only $17.3 \mathrm{~cm}$ of standing water at the Rains soil well (Table 2). The fact that the mean depressional surface storage values calculated using the available DEMs and GIS-based tool developed by Amoah et al. (2012) for these watersheds were $10 \mathrm{~cm}$ or lower suggests that most of the watersheds should have been ponded and/or fully saturated during the September 25-October 5 period as shown in Figure 4. The ponding and/or full saturation across the land surface results in much increased streamflows contributed mostly by shallow surface runoff as shown by Harder et al. (2007) who found the streamflow rate increasing at an exponential rate once the surface ponding exceeds about 4-6 cm on WS 80. This situation most likely occurred on both October 3 and 4 with the total rainfall of $242.6 \mathrm{~mm}$ and $241.4 \mathrm{~mm}$, respectively, at Met 5 . As a result, $90 \%$ of the total 2-day rainfall of $484 \mathrm{~mm}$ on WS 80 contributed to the stream outflow of $436 \mathrm{~mm}$ estimated for those 2 days, which also had the highest peak flow rates.

The estimated preliminary peak flood discharges of $17.3 \mathrm{~m}^{3} / \mathrm{s}$ and $33.9 \mathrm{~m}^{3} / \mathrm{s}$ measured on the watersheds WS 80 and WS 79 on October 4, 2015, with an excess of 250 $\mathrm{mm}$ rainfall within 24 hours on the top of 5-day antecedent rainfall of $170 \mathrm{~mm}+$ at the study site, are significantly higher than the 200-yr flood estimates of $2.3 \mathrm{~m}^{3} / \mathrm{s}$ and $15.3 \mathrm{~m}^{3} / \mathrm{s}$ obtained as preliminary numbers by Amatya and RadeckiPawlik (2007) using the Pearson Type-III flood frequency curves with only 8 and 13 years, respectively, of the historic data (1964-1976) (Table 3). These October 4 extreme flood discharge estimates are also much higher than both the estimates obtained by using empirical equations with only drainage area as a parameter (Feaster et al., 2009) and two additional parameters (percent imperviousness and 50-yr 24hr rainfall intensity) besides the area (Feaster et al., 2014) for rural basins in coastal South Carolina. We speculate that these preliminary estimates of high flood discharges at the peak of the extreme event may have possibly exceeded the 500year flood discharge at these locations. However, Holmes (2015) noted that there is no indication that a 1000-year flood discharge occurred at any of the USGS streamgages in South Carolina. The author also noted that based on some very preliminary analysis, it appears that two stream gages (Black River at Kingstree, South Carolina and Smith Branch at Columbia, South Carolina) have measured peak floods of approximately a 500-year recurrence interval; additionally there appear to be a few more stream gages that experienced a 25-year to 50-year flood, but the majority of the USGS stream gages in South Carolina had flood peaks that were less than 10 -year floods. The author further suggested that it is more accurate to say that "statistically speaking", the rainfall that fell was a 1000-year rain storm, which most likely did not result in a 1000-year flood.

The peak flood discharges observed resulting from this extreme event are similar to hydrologic and water quality responses during the extreme events of 1999, including Hurricane Floyd reported by Shelby et al. (2005) for coastal forested and agricultural watersheds in eastern North Carolina. The authors observed maximum daily flow rates measured across the research watershed, greater during hurricane Floyd than for any other time in a four-year (1996-1999) study period. The 2015 estimated annual runoff coefficient of 0.45 at our study site is similar to the earlier estimate of 0.47 obtained by Harder et al. (2007) for the wet year of 2003 .

The fact that the estimated high peak discharges as a result of the extreme event were found to exceed the estimated design discharges of even 500-yr return periods obtained using recent USGS empirical relationships (Feaster et al., 2014) and other similar methods for low-gradient coastal watersheds and our own flood-frequency analysis (Amatya and Radecki-Pawlik, 2007) for these watersheds suggest a need for reassessing the capacity of existing gauging stations and other cross-drainage structures to minimize the risk of submergence and flooding in the future at this and similar other site. However, the predictions developed by Amatya and Radecki-Pawlik (2007) using only 13 years of data should be re-evaluated using longer periods of observed data for more accurate predictions. Holmes (2015) noted that there is a large amount of uncertainty associated with flood quantile estimates, particularly when a short record of observed data is used. Similarly, it is important to acknowledge uncertainty in the estimates obtained using regionalized regression equations with estimated error of $34-47.7 \%$, depending on the percent chance exceedance event (Feaster et al., 2009), and that the regional regressions were developed using peak flows from sites outside the study area.

Our peak flood estimates obtained by using the measured gauge stage heights in hydraulic equations for compound weirs with varying V-notch angles and a flat weir for WS 80 and an additional dual box culvert on both sides of the weir may also have some uncertainties in the coefficients 
used in these equations (Brater et al., 1996). Furthermore, submergence of weirs and culverts due to extreme storm events, high backwater conditions due to lack of sufficient head drop, outlet controls, tidal fluctuations and even beaver dams characteristic to these low-gradient landscapes may further add uncertainties in high flood discharge estimates (Amatya et al., 1998).

Another major concern in using these empirical and other similar methods involving drainage area to estimate flood discharges on this low gradient landscapes is the accurate determination of the area itself, which is a very challenging task (Amatya et al., 2013, Maceyka and Hansen, 2015). The authors found the drainage area of watershed WS 78 evolving from approximately 3,240 ha in 1964 when it was identified for the study to 7,260 ha in 2008 , and most recently the estimate stands at 5,240 ha based on the DEMs obtained from high resolution LIDAR data and consideration of field verified boundaries and road cross-drainage culverts. During extreme events, like the one in October 2015, there is a possibility of flood water entering the watersheds from outside their boundaries resulting in uncertainty in calculated water and contaminant balances of these very flat watersheds due to extensive flooding and high winds.

\section{CONCLUSIONS AND RECOMMENDATIONS}

This paper summarized the hydrologic effects of an extreme precipitation event that occurred on October 3-4, 2015 which was preceded by 5-days of antecedent wet conditions. Based on the analysis of available hydrometeorological data collected at the site during the extreme event and its comparison with earlier data the following conclusions are made:

1) The month of October 2015 with a $686 \mathrm{~mm}$ total rainfall resulting from an extreme event on October 3-4 with approximately $500 \mathrm{~mm}$ rainfall was the wettest month recorded since the monitoring began in 1946 at the study site. Although the maximum hourly rainfall intensity of $66 \mathrm{~mm} / \mathrm{h}$ recorded during October 3-4, 2015 did not exceed the earlier observed historic intensities at the study site, amounts for all other durations exceeded those observed for similar events during the last 12 years (2003-2014) as well as earlier historic data at the study site. Similarly, the rainfall amounts during this October 2015 event also exceeded established amounts for 6-, 12-, and 24-hr durations for Charleston County, South Carolina.

2) The existing capacities of the gauging station outlets on WS 77, WS 79, and WS 80 watersheds were inadequate to carry their peak flood discharges. Estimates of peak flow were computed by using the measured stage heights and appropriate hydraulic equations for submerged compound weir and culvert outlets.
3) The discharge estimates at two experimental watersheds (WS 79 and WS 80) clearly exceed the estimates computed by using various available empirical methods, up to and including 500-yr return periods.

4) These peak flood discharge estimates are still preliminary and further analysis is needed to ascertain accurate assessments of the peak flood discharges for the submerged outlet conditions.

Estimates of the peak flood discharge for the watersheds WS 77 and WS 78, including developing the complete stormflow hydrographs for all the watersheds in SEF, are currently underway.

To fully assess the impacts of this extreme event on flooding and other ecohydrologic parameters, the recorded rainfall and weather data could be used as inputs to the previously calibrated ecohydrologic models MIKESHEDNDC for the $2^{\text {nd }}$ order watershed WS 79 (Dai et al., 2013b) for predicting the spatially distributed hydrology and carbon and nutrient components, and the SWAT model for the $3^{\text {rd }}$ order watershed (WS 78) (Amatya and Jha, 2011) for predicting the spatially distributed soil moisture and stream flood discharge.

Future studies on these and similar low-gradient coastal plain watersheds should revisit the earlier calculated drainage areas and assess the new areas using high resolution LIDAR-based DEM followed by field validation (Amatya et al., 2013; Maceyka and Hansen, 2015). Furthermore, future studies should revisit the flood frequency analyses and flow duration curves published earlier by Amatya and Radecki-Pawlik (2007) and Amatya et al. (2015) using the longer term data including this extreme event and accordingly assess the capacities of existing culverts and cross-drainage structures on the SEF and beyond in the Francis Marion National Forest.

\section{ACKNOWLEDGMENTS}

The authors would like to acknowledge Paul Conrads, Research Hydrologist, U.S. Geological Survey, Columbia, South Carolina and William F. Hansen, P.H, retired U.S. Forest Service Hydrologist, Columbia, South Carolina for providing valuable comments in their review of the manuscript. Furthermore, the authors express their thanks to Dr. Augustine Muwamba, Postdoctoral Scientist, University of Georgia and Austin Morrison, graduate student, College of Charleston for help with data analysis and Julie Arnold, Biological Technician, USDA Forest Service for help with the GIS map (Figure 1). 


\section{LITERATURE CITED}

Amatya, D.M., T.J. Callahan, and C.C. Trettin. 2016. Synthesis of 10 Years of Studies on Turkey Creek Watershed. In: Headwaters to estuaries: advances in watershed science and management (pp: 23-33), Proc. of the 5th Interagency Conference on Research in the Watersheds. Editors: Stringer, Christina E.; Krauss, Ken W.; Latimer, James S, e-Gen. Tech. Rep. SRS-211. Asheville, NC: U.S.

Amatya, D.M., T.J. Callahan, W.F. Hansen, C.C. Trettin, A. Radecki-Pawlik, and P. Meire. 2015. Turkey Creek - A Case Study of Ecohydrology and Integrated Watershed Management in the Low-Gradient Atlantic Coastal Plain, U.S.A. Journal of Water Resource and Protection, 2015, 7, 792-814, Online July 2015 in SciRes.

Amatya, D.M., C.C. Trettin, S. Panda, H. Ssegane. 2013. Application of LiDAR data for Hydrologic Assessments of Low-gradient Coastal Watershed Drainage Characteristics. J of Geographical Information System, 2013, 5, 171-195.

Amatya, D.M. and M.K. Jha. 2011. Evaluating SWAT Model for a Low Gradient Forested Watershed in Coastal South Carolina. Transactions of the ASABE, 54(6):2151-2163.

Amatya, D.M., T.J. Callahan, C.C. Trettin, A. RadeckiPawlik. 2009. Hydrologic and Water Quality Monitoring on Turkey Creek Watershed, Francis Marion National Forest, SC. ASABE paper \# 09-5999, June 21-24, Annual ASABE Int'l Meeting, Reno, NV.

Amatya, D.M. and C.C. Trettin. 2007. Development of Watershed Hydrologic Research at Santee Experimental Forest, Coastal South Carolina. In: Furniss et al., (eds.), "Advancing the Fundamental Sciences", Proc. of the Forest Service National Earth Sciences Conference, PNW-GTR-689, Vol. I, Portland, OR: U.S. Department of Agriculture, Forest Service, Pacific Northwest Res. Station, pp: 180-190.

Amatya, D.M. and A. Radecki-Pawlik. 2007. Flow Dynamics of Three Forested Watersheds in Coastal South Carolina, U.S.A. Acta Scient. Polonorum-Formatio Circumiectus, 6(2):3-17.

Amatya D.M., M. Miwa, C.A. Harrison, C.C. Trettin, and G. Sun. 2006. Hydrology and water quality of two first order forested watersheds in coastal South Carolina. ASABE Paper \# 06-218. St. Joseph, MI.

Amatya, D.M., G.M. Chescheir, and R.W. Skaggs. 1998. Evaluation of Methods used in Estimating Outflow Rates in the Coastal Watersheds. In pp: 850-855 (vol.1) of Proc. of the 1998 ASCE Int'l Water Res. Engrg. Conf., Memphis, TN, Aug 3-7, 1998.

Amoah, J., D.M. Amatya, and S. Nnaji. 2012. Quantifying Watershed Depression Storage: determination and application in a hydrologic model. Hydrologic Processes. DOI: 10.1002/hyp.9364.
Brater, E.F., H.W. King, J.E. Lindell, and C.Y. Wei. 1996. Handbook of Hydraulics. $7^{\text {th }}$ ed., McGraw-Hill Book Co., NY, USA.

Callahan, T.J., V.M. Vulava, M.C. Passarello, and Garrett, C.G. 2012. Estimating Groundwater Recharge in Lowland Watersheds. Hydrological Processes, 26, 2845-2855.

Carter, L.M., J.W. Jones, L. Berry,V. Burkett, J.F. Murley, J. Obeysekera, P.J. Schramm, and D. Wear. 2014. Chapter 17: Southeast and the Caribbean. In: Melillo, J.M., Richmond T.C. and Yohe, G.W. (eds) Climate Change Impacts in the United States: The Third National Climate Assessment. US Global Change Research Program, Washington, DC. pp. 396-417.

Dai. Z., C.C. Trettin, and D.M. Amatya. 2013a. Effects of Climate Variability on Forest Hydrology and Carbon Sequestration on the Santee Experimental Forest in Coastal South Carolina. USDA Forest Service South. Res. Station, General Technical Report SRS-172, 32p.

Dai, Z., C. Trettin, C. Li, G. Sun., D. Amatya, and H. Li. 2013b. Modeling the impacts of climate variability and hurricane on carbon sequestration in a coastal forested wetland in South Carolina. 2013. Natural Science, Vol.5, No.3, 375-388 (2013) Natural Science doi:10.4236/ ns.2013.53051.

Feaster, T.D., A, J. Gotvald, and J.C. Weaver 2014. Methods for Estimating the Magnitude and Frequency of Floods for Urban and Small Rural Streams in Georgia, South Carolina, and North Carolina, 2011. Scientific Investigations Report 2014-5030, Version 1.1, March 2014, U.S. Geological Survey, Columbia, South Carolina104 p.

Feaster, T.D., A.J. Gotvald, and J.C. Weaver. 2009. Magnitude and Frequency of Rural Floods in the Southeastern United States, 2006. Scientific Investigations Report 2009-5156, U.S. Geological Survey, Columbia, South Carolina, 226.

Grumm, R.H. 2015. Record South Carolina Rainfall Event of 3-5 October 2015. National Weather Service, State College, PA 16803.

Hansen, W.F. 1987. Some Applications of Flood Frequency and Risk Assessment in Forest Management. In: V. P. Singh (ed.), Application of Frequency and Risk in Water Resources, 219-226. (C) 1987 by D. Reidel Publishing Company.

Harder, S.V., Amatya, D.M., Callahan, T.J., Trettin, C.C. and Hakkila, J. 2007. Hydrology and Water Budget for a Forested Atlantic Coastal Plain Watershed, South Carolina. Journal of the American Water Resources Association, 43, 563-575.

Holmes, R. 2015. USGS National Flood Hazard Coordinator, A note from the USGS web page modified 9 October, 2015 https://water.usgs.gov/floods/events/2015/Joaquin/ HolmesQA.html, U.S. Department of Interior, U.S Geological Survey, Reston, Virginia.

Hook, D.D., M.A. Buford, T.M. Williams, 1991. Impact of Hurricane Hugo on the South Carolina Coastal Pine Forest. J. of Coastal Research, SI (8):291-300. 
Hutton, D., N.B. Kaye, and W.D. Martin, III. 2015. Analysis of Climate Change and 24-hour storm Depths for a Range of Return Periods Across South Carolina. J. of South Carolina Water Resources Volume 2, Issue 1, Pages 70-79, 2015.

Jayakaran, A.D., Williams, T.M., Ssegane, H., Amatya, D.M., Song, B. and Trettin, C.C. (2014) Hurricane Impacts on a Pair of Coastal Forested Watersheds: Implications of Selective Hurricane Damage to Forest Structure and Streamflow Dynamics. Hydrol. Earth Syst. Sci., 18, 1151-1164.

Keefer, T.O., K.G. Renard, D.C. Goodrich, P. Heilman, and C. Unkrich. 2015. Quantifying Extreme Rainfall Events and Their Hydrologic Response in Southeastern Arizona. Journal of Hydrologic Engineering, 21(1), January 2016, 1-.1061/(ASCE) HE.1943-5584.0001270

Maceyka, A. and W.F. Hansen. 2015. Enhancing Hydrologic Mapping Using Lidar and High Resolution Aerial Photos on the Francis Marion National Forest in Coastal South Carolina. Proc., 5th Interagency Conference on Research on Watersheds, Charleston, SC.

Marion, D.A., Sun, G., Caldwell, P.V., Chelcy, F., Conrads, P.A., Laird, S.G., Dai, Z., Meyers, J.A.M. and Trettin, C. 2013. Managing Forest Water Quantity and Quality under Climate Change. In: Vose, J. and Kleipzig, K., Climate Change Adaptation and Mitigation Management Options: A Guide for Natural Resource Managers in Southern Forest Ecosystems, CRC Press, 496.

McNulty, S., Myers, J. M., Caldwell, P. and Sun, G. 2013. Climate Change Summary. In: D.N. Wear and Greis, J.G. (eds.) The Southern Forest Futures Project, General Technical Report 178. USDA Forest Service, Ashville, NC, pp. 27-44.

Mizzell, H., M. Malsick, and I. Abramyan. 2014. South Carolina's Climate Report Card: Understanding South Carolina's Climate Trends and Variability. Journal of South Carolina Water Resources, Issue 1, Pages 4-9, June 2014.

NRCS 1986. Urban Hydrology for Small Watershed. TR55. 1986. USDA Natural resources Conservation Service, Washington, D.C. Obeyskara, J. and J.D. Salas. 2016. Frequency of Recurrent Extremes under Nonstationarity. J. Hydrol. Eng., DOI: 10.1061/(ASCE)HE.1943-5584.0001339.

Purvis, J.C., W. Tyler, and S. Sidlow. 1988. Maximum Rainfall Intensity in South Carolina by County. Climate Report No. G32, State Climatology Office, SC Department of Natural Resources, Columbia, South Carolina, June 1988.

Shelby, J.D., G.M. Chescheir, R.W. Skaggs and D.M. Amatya. 2005. Hydrologic and water-quality response of forested and agricultural lands during the 1999 extreme weather conditions in eastern North Carolina. Trans. of the ASABE 48(6): 2179-2188.

Sheridan, J.M., W.H. Merkel, and D.D. Bosch. 2002. Peak

Rate Factors for Flatland Watersheds. ASABE Applied Engineering in Agriculture, 18(1):65-69.
Sivapalan, M., K. Beven, and E.F. Wood. 1987. On Hydrologic Similarity: 2. A Scaled Model of Runoff Prediction. Wat. Res. Res., 23(12): 2266-2278.

Vose, J.M., K.L. Martin, and P.K. Barten. 2016. Applications of Forest Hydrologic Science to Watershed Management in the $21^{\text {st }}$ Century. In: Chapter 15, Forest HydrologyProcesses, Management and Assessment, D.M. Amatya, T.M. Williams, L. Bren, and C. deJong (Eds.), In Press, CABI Publishers, U.K.

Williams, T.M. 1978. Response of shallow water tables to rainfall. P. 363-370 in Proc. of Soil Moisture and Site Productivity Symposium, Myrtle Beach, SC. Ed. W. Balmer. Vol. June.

Williams T.M., Song B., Trettin, C.C., Gresham C.A. 2013. A Review of Spatial Aspects of Forest Damage and Recovery on the South Carolina Coast Following Hurricane Hugo. J. Geogr. Nat Disast, 2013, 3:2, 7p. 